\title{
KOMUNIKASI MATEMATIS SISWA DALAM MEMECAHKAN MASALAH ALJABAR TARIK TAMBANG
}

\author{
${ }^{1}$ Ucik Fitria Handayani \\ ${ }^{1}$ IAI-Al-Qolam Malang, Jl. Raya Putat Lor Gondanglegi Malang, (0341)878661 \\ e-mail: ucik@alqolam.ac.id
}

\begin{abstract}
Abstrak
Komunikasi matematis adalah kegiatan bertukar berbagi ide, pikiran, dan informasi sehingga dapat memperjelas pemahaman. Kemampuan matematis harus dibiasakan dan dikembangkan dalam proses belajar mengajar matematika. Penelitian ini bertujuan untuk mendeskripsikan komunikasi matematis siswa dalam memecahkan masalah aljabar tarik tambang melalui penyelesaian masalah dan wawancara dengan berdasarkan standar NCTM. Hasil penelitian ini adalah (1) kemampuan komunikasi matematis subjek S-A memenuhi empat standar komunikasi di NCTM, dimana sejak awal sudah dapat mengkomunikasikan permasalahan matematika yang diberikan sesuai dengan kemampuannya, (2) kemampuan komunikasi matematis subjek S-B hanya memenuhi dua standar, akan tetapi subjek S-B mengalami peningkatan komunikasi matematika dengan menemukan strategi lain setelah mendengarkan penjelasan dari S-A.
\end{abstract}

Kata Kunci: komunikasi matematika, aljabar

\begin{abstract}
Mathematical communication is the activity of sharing ideas, thoughts, and information so that it can clarify understanding. Mathematical abilities must be familiarized and developed in the process of teaching and learning mathematics. This study aims to describe students' mathematical communication in solving tug of war algebra problems through problem solving and interviews based on NCTM standards. The results of this study are (1) the mathematical communication skills of the SA subject meet the four communication standards in NCTM, where since the beginning it has been able to communicate the given mathematical problems according to their abilities, (2) the mathematical communication skills of the SB subject only meet two standards, but the SB subject increased
\end{abstract}

Keywords: mathematics communication, algebra

\section{PENDAHULUAN}

Komunikasi termasuk hal dasar dan penting dalam proses belajar dan mengajar khususnya matematika. Sejalan dengan Pertiwi, dkk (2020) dan Syafina \& Pujiastuti (2020) yang menjelaskan bahwa komunikasi berperan penting dalam bidang matematika, hal ini dikarenakan dalam kegiatan pembelajaran menekankan kemampuan komunikasi dan pemecahan masalah. Rifdah \& Priatna (2019) juga menambahkan bahwa keterampilan komunikasi siswa perlu dikembangkan dalam proses pembelajaran matematika. Hal ini dikarenakan komunikasi matematika termasuk salah satu proses standar dalam pembelajaran matematika (Putri \& Musdi, 2020). Oleh karena itu, kemampuan komunikasi matematika harus dikuasai dan dikembangkan oleh tiap siswa di sekolah. 
Komunikasi matematika merupakan kegiatan bertukar berbagi ide, pikiran, dan informasi sehingga dapat memperjelas pemahaman. Dengan komunikasi, siswa dapat terbantu dalam bertukar pikiran dan gagasan, sehingga siswa lebih mudah memahami dalam proses pembelajaran matematika (Syafina \& Pujiastuti, 2020). Kemampuan komunikasi matematika siswa dapat dilihat pada saat siswa menyampaikan ide matematika secara tulis maupun lisan. Komunikasi dalam matematika tidak hanya berbicara dan menulis, namun juga dalam hal menerima dan menyerap informasi serta gagasan orang lain, seperti medengarkan dan membaca. Sehingga, hal ini perlu diperhatikan dikarenakan untuk mempersiapkan masa depan dimana dunia perguruan tinggi menekankan kemampuan berkomunikasi dengan lebih jelas, baik secara lisan maupun tulisan. Seperti yang disampaikan Putri \& Musdi (2020) komunikasi dalam bidang matematika dapat membantu guru dalam memahami kemampuan siswa dalam pemahamannya tentang konsep matematika yang sudah dipelajari.

Pada proses pembelajaran matematika kemampuan siswa dalam berkomunkasi sangatlah diperlukan, khususnya dalam penggunaan simbol matematika. Salah satu yang menjadi ciri khas kemampuan komunikasi matematika siswa adalah dalam penggunaan berbagai simbol matematika (Netti, dkk, 2019). Pada saat siswa berpikir, berdiskusi, menyampaikan pendapat, menganalisis matematika artinya siswa belajar berkomunikasi secara matematis (Putri \& Musdi, 2020). Tidak hanya siswa yang harus dapat mengkomunikasikan simbol matematika, akan tetapi guru juga memiliki tantangan dalam memahami dan mengkomunikasikannya. Guru harus memperhatikan dan membiaskaan kemampuan komunikasi matematika siswa dalam pembelajaran karena pengetahuan siswa dibentuk melalui komunikasi (Netti, dkk, 2019).

Pembelajaran matematika di sekolah diharapkan dapat melatih dan membiasakan kemampuan komunikasi siswa dalam memecahkan masalah. Seperti halnya yang disampaikan Hodiyanto (2017), bahwa kemampuan komunikasi matematika siswa dalam memecahkan masalah harus dikembangkan dalam proses pembelajaran di sekolah. Permasalahan matematika harus dipecahkan dengan prosedur tidak rutin dan mengandung tantangan dalam proses pemecahannya. Dengan adanya hasil kerja siswa, guru dapat mengetahui kesalahan yang mungkin siswa alami, baik kesalahan konsep maupun kesalahan teknik. Melalui hasil kerja tersebut, guru juga dapat melihat seberapa banyak pengetahuan yang diperoleh siswa dan sejauh mana pemahaman siswa tentang materi, salah satunya adalah materi aljabar. Sehingga, hal ini dapat membantu guru dalam merancang dan melaksanakan pembelajaran mendatang. 
Aljabar merupakan salah satu materi yang ada pada bidang studi matematika jenjang SMP. Utami, dkk (2020) juga menyampaikan bahwa terdapat banyak sekali materi matematika yang harus dikuasi salah satunya yakni masalah aljabar. Konsep aljabar perlu dikenalkan kepada siswa karena akan berguna diberbagai bidang matematika yang akan dipelajari oleh siswa. Pembelajaran konsep aljabar kepada siswa bertujuan agar siswa dapat berpikir logis, analitis, sistematis, kritis, kreatif, dan kerjasama. Terdapat berbagai permasalahan pada materi aljabar, salah satunya adalah masalah tarik tambang. Masalah tarik tambang dalam penelitian ini merupakan permasalahan tarik tambang antara dua jenis binatang dengan berbagai komposisi yang berbeda. Masalah tarik tambang digunakan untuk mengetahui kemampuan komunikasi siswa dalam memecahkan masalah tersebut dengan menggunakan konsep aljabar.

Tidak sedikit siswa yang menyerah dalam memecahkan masalah yang diberikan. Sehingga lebih memilih untuk tidak memecahkannya sendiri atau pilih melihat jawaban orang lain. Siswa akan cenderung menyontek apabila tidak dapat menjawab pertanyaan dari guru (Putri \& Musdi, 2020). Kurangnya kemampuan komunikasi matematika siswa tentunya akan berpengaruh terhadap hasil belajarnya, sehingga diperlukan upaya guru dalam mengembangkan kemampuan komunikasi matematika siswa. Pratiwi, dkk (2020); Hajj, dkk (2021); Fitriani, dkk (2021) menambahkan bahwa pemecahan masalah dan komunikasi matematika sangatlah perlu ditekankan dalam proses pembelajaran matematika di kelas. Hal ini dikarenakan pembelajaran komunikasi dalam matematika dapat membantu siswa untuk aktif mengembangkan interaksi dan membiasakan dalam penyampaian ide di dalam kelas.

Akan tetapi, pada kenyataannya kemampuan komunikasi matematika siswa masih kurang optimal. Berdasarkan observasi pada salah satu SMP Swasta di Provinsi Jawa Timur, kemampuan siswa dalam mengkomunikasikan simbol matematika, diagram, gambar, dan kalimat matematika masih rendah. Hal ini terlihat pada saat siswa belum bisa memahami dan mengkomunikasikan ketika diberikan permasalahan matematika yang melibatkan beberapa simbol matematika, gambar, dan diagram. Selain itu, kegiatan pembelajaran yang dilaksanakan juga masih terpusat pada guru. Akibatnya, siswa menjadi kurang aktif dalam proses pembelajaran dan kemampuan komunikasi matematika siswa belum optimal. Penelitian terdahulu oleh Hajj, dkk (2021) juga menjelaskan bahwa lebih dari 50\% nilai siswa kurang dari KKM, sehingga kemampuan komunikasi matematis siswa masih belum optimal. Selain itu Isa \& Rahmani (2021) juga menambahkan bahwa Sebagian besar kemampuan siswa dalam memecahkan permasalahan masih rendah, bahkan masih ada siswa yang tidak 
tertarik dengan masalah kontekstual yang dimana lebih membutuhkan kemampuan komunikasi matematis.

Adanya kesenjangan antara pentingnya komunikasi dengan kemampuan komunikasi siswa yang lemah, terdapat beberapa penelitian yang telah membahasnya. Syafina \& Pujiastuti (2020) menyebutkan bahwa presentase rata-rata kemampuan komunikasi matematis siswa dibawah 50\%. Hal ini terlihat bahwa masih banyak siswa yang kemampuan komunikasinya kurang. Selain itu, Qohar (2011) menyebutkan bahwa siswa SMP masih kurang baik dalam melakukan komunikasi baik lisan maupun tulisan. Pertiwi, dkk (2020) menambahkan bahwa siswa dengan kemampuan matematis rendah cenderung memiliki kemampuan komunikasi yang kurang akurat. Dalam hal ini siswa kurang terbiasa dalam mengkomunikasikan simbol, diagram, gambar dan kalimat matematika dalam proses pembelajaran matematika. Oleh karena itu, peneliti tertarik melakukan penelitian terkait kemampuan komunikasi matematika siswa dalam memecahkan masalah.

\section{METODE PENELITIAN}

Penelitian ini menggunakan pendekatan deskriptif kualitatif. Penelitian dilaksanakaan pada salah satu SMP swasta di Provinsi Jawa Timur. Penelitian dilaksanakan pada siswa kelas VIII-D yang termasuk kelas dengan kemampuan matematika siswa bermacam-macam. Siswa kelas VIII-D diberikan permasalahan matematika aljabar tentang tarik tambang. Subjek penelitian ini adalah dua siswa yang memiliki kemampuan tinggi dan kemampuan rendah berdasarkan hasil jawaban siswa. Siswa kemampuan tinggi yakni S-A dan siswa kemampuan rendah adalah S-B. Kemudian, siswa diminta untuk mengkomunikasikan atau menjelaskan memberikan jawabannya secara lisan pada saat wawancara.

Berdasarkan hasil jawaban siswa secara lisan dan tulisan, maka akan dianalisis berdasarkan standar kemampuan komunikasi matematis siswa menurut NCTM (2000). Terdapat 4 standar kemampuan komunikasi matematis siswa, yakni mengatur pemikiran matematis melalui komunikasi, mengkomunikasikan pemikiran matematis dengan jelas, menganalisis dan mengevaluasi pemikiran matematika dan strategi orang lain, dan menggunakan Bahasa matematika untuk mengekspresikan ide-ide matematika dengan tepat. Berikut instrumen permasalahan matematika aljabar tentang tarik tambang yang diberikan kepada siswa. 

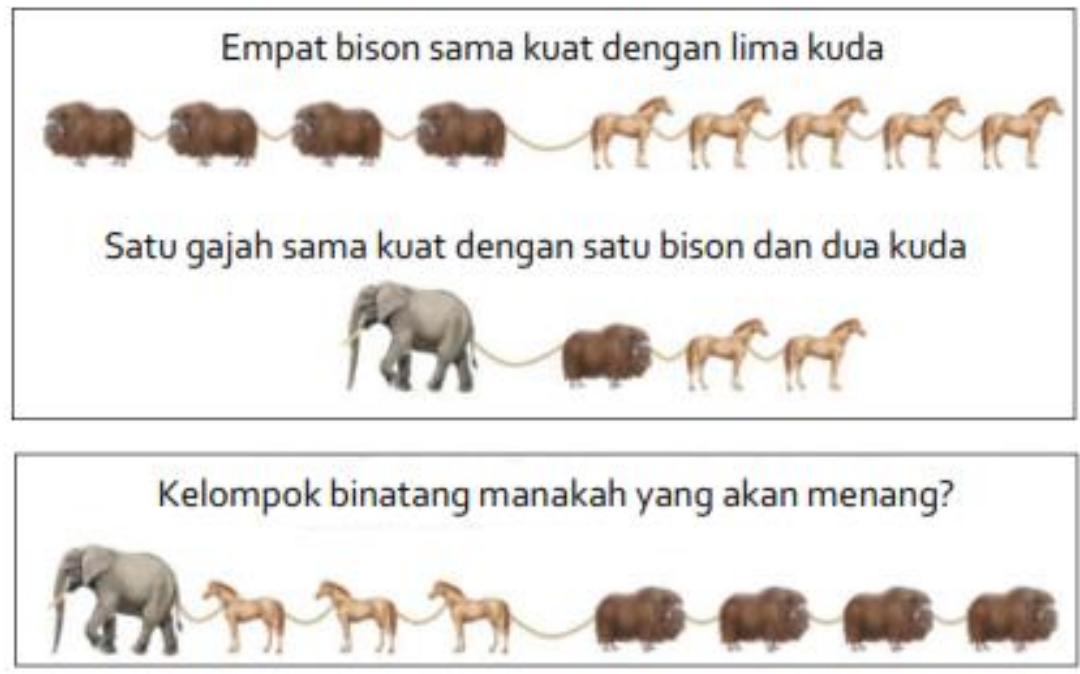

Gambar 1. Permasalahan Matematika

(Sumber: Workshop Daring Pembelajaran Matematika dengan Matematika Realistik)

\section{HASIL DAN PEMBAHASAN}

Kegiatan penelitian diawali dengan memberikan permasalahan matematika kepada siswa kelas VIII-D. Berdasarkan hasil jawaban siswa dipilih 2 siswa sebagai subjek penelitian berdasarkan nilai tertinggi dan terendah. S-A merupakan subjek yang mendapatkan nilai tertinggi dan S-B merupakan subjek dengan nilai terendah. Kemudian, kedua subjek diwawancarai oleh peneliti secara langsung untuk mengetahui cara siswa mengkomunikasikan jawaban yang mereka tuliskan. Hasil pekerjaan siswa dan wawancara dengan peneliti akan dianalisis berdasarkan 4 standar kemampuan komunikasi matematis siswa. Berikut disajikan hasil analisis berdasarkan 4 standar kemampuan komunikasi matematis siswa:

\section{Mengatur Pemikiran Matematis Melalui Komunikasi}

Wawancara dilaksanakan secara bersamaan dengan dua subjek penelitian yang telah ditentukan. Dengan memberikan permasalahan matematika kepada siswa diperoleh informasi bahwa permasalahan matematika yang diberikan memberikan manfaat untuk siswa dalam mengekspresikan ide dan menyerap informasi.

Berdasarkan hasil jawaban subjek, peneliti menanyakan terkait alasan dari jawaban yang dituliskan. Pada saat peneliti menanyakan, subjek S-A berusaha untuk mengkomunikasikan pemikiran matematis dengan jelas dan meyakinkan. Sedangkan, subjek S-B sulit untuk mengekspresikan ide matematisnya atau pendapatnya padahal sebenarnya sudah ada dalam pikirannya. Qohar (2011) dalam penelitiannya menyebutkan bahwa siswa 
kesulitan dalam mengungkapkan pendapat meskipun idenya sudah dipikirkan. Artinya subjek S-B belum dapat menerjemahkan soal ke dalam model matematika (Hajj, Lestari, \& Imami, 2021). Hal ini bisa dikarenakan siswa belum terbiasa menyelesaikan permasalahan kontekstual dengan mengubahnya ke dalam bentuk aljabar (Azis \& Sudihartinih, 2021).

Berdasarkan hasil wawancara antara peneliti dengan dua subjek penelitian diperoleh informasi bahwa subjek S-A dapat memberikan jawaban dan alasan terkait permasalahan matematika yang diberikan dengan tepat. Subjek S-A menjelaskan bahwa pada kelompok kanan yakni 4 bison bisa diganti dengan 5 kuda pada bentuk pertama dan gajah di kelompok kiri bisa diganti dengan satu bison dan dua kuda seperti pada bentuk kedua. Subjek S-A juga menambahkan bahwa artinya pada kelompok kiri ada lima kuda dan satu bison, dan yang kelompok kanan hanya ada lima kuda. Kemudian subjek S-A juga menyampaikan bahwa yang menang adalah kelompok kiri karena ada tambahan satu bison. Artinya, dalam hal ini subjek S-A dapat menyampaikan dengan jelas mengenai alasan dalam pemecahan masalah matematika yang diberikan. Sejalan dengan Hendriana \& Kadarisma (2019) yang menjelaskan bahwa kemampuan komunikasi matematis harus dapat memberikan alasan yang masuk akal dalam pemecahan permasalahan matematika, mengubah ke dalam model matematika, dan dapat menggambarkan ide matematika dalam bentuk uraian yang sesuai. Dengan kemampuan komunikasi matematika yang baik maka siswa dapat terampil dalam memecahkan berbagai permasalahan matematika yang diberikan (Isa \& Rahmani, 2021).

Berikut disajikan cuplikan hasil pekerjaan subjek S-B dalam menyelesaikan permasalahan yang diberikan.

$$
\begin{aligned}
& 4 \text { bison }=5 \text { Kuda } \\
& 1 \text { Gajah }=1 \text { bison } 2 \text { kuda } \\
& 1 \text { Gajah } 3 \text { kuda melawan a bison } \\
& \text { jadi kelompok binatang yang menang adatah } \\
& 1 \text { Gajah } 3 \text { kuder }
\end{aligned}
$$

Gambar 1. Hasil Jawaban Subjek S-B

Berbeda dengan subjek S-B dimana ia tidak dapat menjelaskan alasan dalam menuliskan jawabannya. Berdasarkan hasil wawancara, subjek S-B menyampaikan bahwa jawaban yang dituliskannya hanya berdasarkan perkiraan saja tanpa adanya alasan yang jelas. Subjek S-B tidak paham dengan permasalahan yang diberikan, sehingga sulit 
mengkomunikasikan alasannya. Seperti yang disampaikan Maulidya \& Hidayati (2019) bahwa apabila siswa tidak memahami persoalan, maka siswa akan kesulitan dalam menyampaikan ide matematisnya secara tulis maupun lisan. Artinya subjek S-B belum dalam menerjemahkan soal ke dalam model matematika (Hajj, Lestari, \& Imami, 2021). Komunikasi matematis siswa dalam hal ini memerlukan kemampuan representasi siswa dengan menggunakan pendekatan Bahasa (Isa \& Rahmani, 2021).

Subjek S-A menjelaskan ide matematisnya dengan menggunakan bahasa sendiri dan sederhana. Hal ini terlihat pada saat subjek S-A menyampaikan kata-kata "diganti” yang pada dasarnya dalam matematika artinya adalah "substitusi". Pada percakapan tersebut, peneliti berperan untuk menggali informasi lebih mendalam dari subjek penelitian agar dapat menjelaskan ide matematisnya secara lebih rinci. Subjek S-A dapat menyampaikan alasan dalam proses pemecahan masalah matematika yang diberikan sehingga dapat mengilustrasikan ide matematika dalam bentuk tulisan. Artinya dalam hal ini dapat dikatakan bahwa subjek S-A memenuhi standar komunikasi yaitu mengatur pemikiran matematis melalui komunikasi. Sesuai dengan yang disampaikan Maulidya \& Hidayati (2019) dalam penelitiannya bahwa kemampuan komunikasi matematis siswa dapat dilihat pada saat siswa menyampaikan pendapat/konsep matematis baik secara lisan ataupun tulisan. Siswa yang dapat menguraikan permasalahan kontekstual kemudian mengkomunikasikannya dalam bentuk aljabar termasuk siswa dengan kemampuan komunikasi matematis tinggi (Azis \& Sudihartinih, 2021).

\section{Mengkomunikasikan Pemikiran Matematis dengan Jelas}

Berdasarkan hasil pekerjaan siswa dan wawancara yang telah dilakukan sebelumnya, subjek S-B tidak dapat memahami proses pemecahan masalah yang diberikan. Secara langsung subjek S-A memberikan penjelasaan kepada subjek S-B terkait langkah-langkah yang digunakan dalam proses pemecahan masalah matematika. Subjek S-A menjelaskan bahwa satu gajah sama dengan satu bison ditambah dua kuda. Kemudian gajahnya yang di kelompok kiri diganti dengan kelompok kanan bentuk kedua karena sama. Artinya kelompok kiri menjadi lima kuda dan satu bison.

Pada proses penjelasan yang dilakukan oleh subjek S-A, subjek S-B secara perlahan dapat memahami dengan penjelasannya. Proses pembelajaran matematika memang membutuhkan konsep penalaran dan komunikasi, sebab proses berpikir siswa akan diketahui siswa lain jika dikomunikasikan (Isa \& Rahmani, 2021). Subjek S-A melanjutkan 
penjelasannya bahwa empat bison yang kelompok kanan diganti dengan lima kuda pada kelompok kanan bentuk pertama. Pada akhirnya subjek S-A menyampaikan bahwa kelompok yang menang adalah kelompok kiri. Akan tetapi, subjek S-B langsung menyela dengan menanyakan kenapa kelompok kiri yang menang. Kemudian subjek S-A kembali menjelaskan jika kelompok yang kiri awalnya ada lima kuda dan satu bison dan kelompok yang kanan hanya ada lima kuda, jadi kelompok kiri lebih satu bison dan artinya kelompok kiri yang menang. Mendengar penjelasan subjek S-A secara berturut-turut, subjek S-B paham dan akhirnya mengerti alasan kelompok kiri yang menang. Hal ini terlihat bahwa komunikasi matematis siswa di kelas terjadi dimana siswa menyampaikan ide matematika yang sedang dipelajari (Hajj, Lestari, \& Imami, 2021).

Berdasarkan obrolan yang dilaksanakan oleh kedua subjek penelitian, terlihat dimana subjek S-A secara langsung merespons dan berusaha untuk menjelaskan lebih rinci kepada subjek S-B tentang ide matematisnya terkait proses pemecahan masalah matematika yang sudah dilakukannya. Dalam berkomunikasi harus dapat menyampaikan/menyalurkan ide, pendapat, gagasan dan apa yang ada dalam pikiran kepada orang lain sehingga orang lain paham tentang apa yang sudah disampaikan. Oleh karena itu kemampuan komunikasi matematis siswa sangatlah penting untuk dikuasai oleh masing-masing siswa (Hajj, Lestari, \& Imami, 2021). Dalam hal ini, subjek S-A berusaha untuk menjelaskan ulang tentang proses pemecahan masalah matematika yang dilakukannya. Sejalan dengan NCTM (2000) bahwa siswa harus belajar untuk meyakinkan kepada orang lain dan apakah orang lain dapat memahami apa yang sudah dijelaskan. Oleh karena itu, subjek S-A dapat memenuhi standar komunikasi yakni mengkomunikasikan pemikiran matematis dengan jelas. Dalam hal ini membuktikan bahwa komunikasi sangatlah penting untuk menyampaikan ide-ide matematika yang digunakan memecahkan permasalahan matematika agar ide tersebut dapat dipahami oleh orang lain (Isa \& Rahmani, 2021).

\section{Menganalisis dan Mengevaluasi Pemikiran Matematika dan Strategi Orang Lain}

Pada proses penjelasan yang dilakukan oleh subjek S-A, subjek S-B sempat menyela dengan menanyakan kenapa kelompok kiri yang menang. Kemudian subjek S-A kembali menjelaskan jika kelompok yang kiri awalnya ada lima kuda dan satu bison dan kelompok yang kanan hanya ada lima kuda, jadi kelompok kiri lebih satu bison dan artinya kelompok kiri yang menang. Mendengar penjelasan subjek S-A secara berturut-turut dan seksama, subjek S-B paham dan akhirnya mengerti alasan kelompok kiri yang menang. Hal ini 
dikarenakan kemampuan komunikasi dalam matematika memang membutuhkan sebuah pembelajaran dan latihan (Muzaki \& Yulianti, 2021). Dengan menyampaikan pemahamannya mengenai materi yang dipahaminya beserta alasannya, diharapkan siswa akan lebih nyaman dan senang dengan pembelajaran matematika dan dapat merefleksikan pemahamannya. Sejalan dengan NCTM (2000) dimana siswa harus belajar dan menyelidiki pemikiran orang lain untuk mengklarifiksi ide yang belum dikembangkan. Matematika dalam hal ini digunakan sebagai alat komunikasi siswa dengan siswa untuk menyampaikan ide yang dipahami (Isa \& Rahmani, 2021).

Selanjutnya peneliti menanyakan kepada subjek S-B apakah memiliki ide matematis lain tentang pemecahan masalah matematika yang sudah diberikan. Kemudian subjek S-B menyampaikan bahwa ia memiliki cara lain yakni dengan mengganti gajah dengan kelompok kanan bentuk kedua, kemudian lima kuda diganti dengan empat bison pada kelompok kiri bentuk pertama. Kelompok kiri akan menjadi lima bison dan kelompok kanan hanya ada empat bison, sehingga kelompok kiri yang menang. Subjek S-A merespon dengan baik dan menyampaikan bahwa strategi yang digunakan subjek S-B lebih efektif. Komunikasi sangatlah penting untuk menyampaikan ide-ide matematika yang digunakan memecahkan permasalahan matematika agar ide tersebut dapat dipahami oleh orang lain (Isa \& Rahmani, 2021).

Pada percakapan tersebut, peneliti berusaha memancing komunikasi subjek S-B dengan menggali informasi, ide, gagasan dan apa yang dipikirkan subjek S-B dengan menanyakan cara atau ide matematis lain dalam memecahkan masalah matematika tersebut. Ternyata subjek S-B memiliki strategi lain yang berbeda dengan strategi yang digunakan oleh subjek S-A. NCTM (2000) menjelaskan bahwa siswa diharapkan tidak hanya menyajikan dan menjelaskan ide matematis, akan tetapi juga menganalisis, membandingkan makna, keefisienan dan keindahan dari strategi yang beragam. Pada bagian ini pula, subjek S-B yang awalnya belum mampu mengkomunikasikan alasan dari jawabannya kemudian mendengarkan penjelasan dari subjek S-A dengan seksama pada akhirnya memiliki strategi lain dalam memecahkan masalah matematika tersebut. Dalam hal ini membuktikan bahwa komunikasi sangatlah penting untuk menyampaikan ide-ide matematika yang digunakan memecahkan permasalahan matematika agar ide tersebut dapat dipahami oleh orang lain (Isa \& Rahmani, 2021). Artinya dalam hal ini komunikasi matematis merupakan kemampuan menyalurkan ide matematika sehingga terjadinya transfer materi antar siswa (Fitriani, Siregar, \& Novitasari, 2021) 
Berdasarkan hal ini subjek S-A dan subjek S-B memenuhi standar komunikasi yakni menganalisis dan mengevalusai pemikiran matematika dan strategi orang lain. Kemudian karena subjek S-B dapat menjelaskan strategi lain dalam pemecahan masalah maka subjek SB dapat memenuhi standar komunikasi yaitu mengatur pemikiran matematis melalui komunikasi.

\section{Menggunakan Bahasa Matematika Untuk Mengekspresikan Ide-Ide Matematika dengan Tepat}

$$
\begin{aligned}
& \text { Kelompok gajah } 3 \text { Kucla } \\
& k \text { arena } \beta+2 k \quad \text { S-A menuliskan Gajah tidak dengan }
\end{aligned}
$$

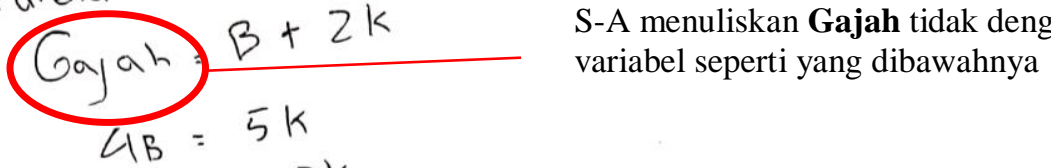

$$
\begin{aligned}
& K 1=6+3 k \\
& k 2=4 B \\
& k_{1}=B^{*}+5 k(3 k u d a+2 k u d a) \\
& k 2=4 B=5 k \\
& \begin{array}{l}
\text { maka, kelompok Pertama yang akan } \\
\text { memenangkan tarik tambang, karena } \\
\text { kelompok lebih unggul }
\end{array} \\
& \text { Bison }
\end{aligned}
$$

Gambar 2. Hasil Jawaban Subjek S-A

Berdasarkan hasil jawaban subjek S-A dalam bentuk lisan dan tulisan, dapat dilihat bahwa subjek S-A dapat menangkap informasi dari permasalahan matematika yang diberikan. Dengan membaca soal, subjek S-A dapat menyampaikan kembali apa yang telah diketahui dari soal dalam bentuk komunikasi tertulis dan lisan. Kemampuan komunikasi siswa dapat dilihat apabila siswa dapat menuliskan permasalahan dengan menggunakan simbol-simbol dalam matematika (Muzaki \& Yulianti, 2021). Berdasarkan hasil jawaban subjek S-A secara tertulis dapat diketahui bahwa subjek S-A mengkonversi gambar ke dalam bahasa matematika, yakni dengan menyimbolkan gambar tersebut dalam bentuk variabel. Walaupun pada penulisannya masih terdapat kesalahan teknik berupa ketidakkonsistenan dalam penyimbolan gajah. Seperti pada penelitiannya Aziz \& Sudihartinih (2021) yang menjelaskan bahwa seringkali siswa tidak teliti dalam menuliskan arti variabel yang dipakai dalam pemecahan masalah matematika. 
Selanjutnya subjek S-A dapat mengolah informasi, menyelesaikan masalah dan menerjemahkan ide matematika yang ada pada pikirannya dalam bentuk tulisan. Subjek S-A juga menuliskan kesimpulan beserta alasannya berdasarkan beberapa langkah yang telah dilakukan. Kemampuan komunikasi siswa dapat dilihat apabila siswa dapat menuliskan idematenatika pada saat memecahkan permasalahan matematika (Muzaki \& Yulianti, 2021). Oleh karena itu, subjek S-A dapat memenuhi standar komunikasi matematis yakni menggunakan Bahasa matematika untuk mengekspresikan ide-ide matematika dengan tepat.

\section{SIMPULAN DAN SARAN}

Berdasarkan hasil dan pembahasan yang telah diuraikan, dapat ditarik kesimpulan sebagai berikut. (1) Subjek S-A dapat mengkomunikasikan secara matematis dan memenuhi standar komunikasi dalam NCTM, yaitu mengatur pemikiran matematis melalui komunikasi dengan bahasa yang sederhana, mengkomunikasikan pemikiran matematis dengan jelas, menganalisis dan mengevaluasi pemikiran matematika dan strategi orang lain dengan cara menilai dan menghargai pendapat temannya sebagai strategi yang lebih cepat, dan menggunakan Bahasa matematika untuk mengekspresikan ide-ide matematika dengan tepat, walaupun masih terdapat ketidakkonsistenan dalam penulisan banyaknya variabel. (2) Subjek S-B awalnya merasa kesulitan dalam mengkomunikasikan ide matematikanya. Akan tetapi, dengan mendengarkan penjelasan subjek S-A secara seksama maka subjek S-B dapat menjelaskan strategi lain yang lebih mudah. Terdapat dua standar komunikasi yang dapat dipenuhi oleh subjek S-B. Pertama, dapat memenuhi standar komunikasi menganalisis dan mengevaluasi pemikiran matematika dan strategi orang lain dengan cara memperhatikan dengan seksama penjelasan temannya hingga akhirnya dapat memahami ide matematis dalam pemecahan masalah. Kedua, dapat memenuhi standar komunikasi mengatur pemikiran matematis melalui komunikasi dengan bahasa yang sederhana yakni dengan menjelaskan strategi berbeda dalam pemecahan masalah matematika.

\section{DAFTAR PUSTAKA}

\section{Books}

NCTM. (2000). Principles and Standards for School Mathematics. United States of America: The National Council of Teachers of Mathematics, Inc.

\section{Online Journal}


Azis, B. A., \& Sudihartinih, E. (2021). Kemampuan Komunikasi Matematis Siswa Kelas VII MTs Negeri 2 Kotamobagu Pada Materi Aljabar. Jurnal Equation, 4(1), 91-102.

Fitriani, Siregar, Y. A., \& Novitasari, W. (2021). Analisis kesulitan kemampuan komunikasi matematika mahasiswa menggunakan aplikasi google classroom pada matakuliah aljabar. Jurnal of Didactic Mathematics, 2(1), 18-25.

Hajj, I. I., Lestari, K. E., \& Imami, A. I. (2021). Analisis Kemampuan Komunikasi Matematis Siswa MTs dalam Menyelesaikan Soal Bentuk Aljabar. MAJU, 8(1), 474-479.

Hendriana , H., \& Kadarisma, G. (2019). Self-Efficacy dan Kemampuan Komunikasi Matematis Siswa SMP. JNPM (Jurnal Nasional Pendidikan Matematika), 3(1), 153 164.

Hodiyanto. (2017). Kemampuan Komunikasi Matematis dalam Pembelajaran Matematika. AdMathEdu, 7(1), 9-18.

Isa, M., \& Rahmani. (2021). Analisis Kemampuan Komunikasi Matematika Mahasiswa pada Matakuliah Aljabar. Jurnal Kinerja Kependidikan, 3(1), 204-212.

Maulidya, A. N., \& Hidayati, N. (2019). Analisis Kemampuan Komunikasi Matematis Siswa SMP Pada Soal Himpunan. Prosiding Seminar Nasional Matematika dan Pendidikan Matematika, (p. Sesiomadika 2019).

Muzaki, A., \& Yulianti, S. (2021). Analisis Kemampuan Komunikasi Matematis pada Materi Bentuk Aljabar Kelas VII SMP N 1 Utan. Jurnal Ilmiah IKIP Mataram, 8(1), 197205.

Netti, S., Khairul, \& Amelia, P. (2019). Student's Mathematical Communication Skill Based on The Assimilation and Accommodation Framework. International Journal of Trends in Mathematics Education Research, 2(3), 133-137.

Pertiwi, E. D., Khabibah, S., \& Budiarto, M. T. (2020). Komunikasi Matematika dalam Pemecahan Masalah. Jurnal Cendekia: Jurnal Pendidikan Matematika, 4(1), 202-211.

Putri, N. D., \& Musdi, E. (2020). Analysis of students Initial mathematical communication skills in mathematics learning. Journal of Physics: Conference Series, 1554(2020), 16.

Qohar, A. (2011). Pengembangan Instrumen Komunikasi Matematis Untuk Siswa SMP. Lomba dan Seminar Matematika, (pp. 44-57).

Rifdah, \& Priatna, N. (2020). The relationship between mathematics resilience and mathematics communication skills. Journal of Physics: Conference Series, 1521(2020), 1-5.

Syafina, V., \& Pujiastuti, H. (2020). Analisis Kemampuan Komunikasi Matematis Siswa Pada Materi SPLDV. MAJU, 7(2), 118-125.

Utami, R. E., Ekawati, C., \& Handayanto, A. (2020). Profil Kemampuan Berpikir Aljabar dalam Memecahkan Masalah Matematika ditinjau dari Gaya Kognitif Reflektif Siswa SMP. Jurnal Ilmiah Pendidikan Matematika, 5(1), 13-24. 